\title{
SUB-DISCIPLINES IN MANAGEMENT SCIENCES: REVIEW OF CLASSIFICATIONS IN POLISH AND WORLDWIDE RESEARCH PRACTICE
}

\author{
Remigiusz Kozłowski*, Marek Matejun**
}

\begin{abstract}
One of the features of management sciences is their strong sub-disciplinary nature which results in distinguishing specific research specializations. This process is a consequence of the eclectic character of management and is associated with the dynamic emergence of new research areas and practical applications. Taking this into account, the aim of the paper is to identify and assess the scope, characteristics and development prospects of selected classifications of sub-disciplines in management sciences in Polish and worldwide research practice. The aim is realized on the basis of the research encompassing 13 selected classifications and opinions of 31 experts representing the scientific community from Poland and China. The results indicate a wide variety of the analyzed classifications which are characterized by different application goals, scope, characteristics and classification logic.
\end{abstract}

Keywords: management sciences, sub-disciplines in management sciences, classification of sciences, identity of management sciences.

\section{INTRODUCTION}

Management sciences are a relatively young discipline which, however, can boast rich scientific and practical achievements. Areas of interest in management sciences continue to develop and expand, and their substantive scope is so complex that so far there is no commonly shared view regarding this subject (Zakrzewska-Bielawska, 2012,

\footnotetext{
* University of Lodz. E-mail: rjk5511@gmail.com

** Lodz University of Technology. E-mail: matejun@p.lodz.pl
} 
pp. 15-17). Scientific sub-disciplines, understood as substantively separate, well-developed and relatively permanent research specializations ${ }^{*}$, play an important role in classifying this scope and building the identity of management sciences (Sudoł, 2014, p. 29). They are a consequence of the general trend to classify sciences into domains, areas and sub-areas (Mendes, 2016). Sub-disciplines significantly determine development prospects of this scientific discipline by strongly influencing the substantive scope, methodological rigor and level of integration of management sciences.

Members of the scientific community continue to debate classification objectives, rules and logic as well as the substantive scope of classifications of sub-disciplines in management sciences (Cyfert et al., 2014; Łupicka, 2014, pp. 70-72; Mingers \& Leydesdorff, 2015) leading to the formulation of various practical solutions. Taking this into account, the aim of the paper is the identification and assessment of the scope, characteristics and development prospects of selected classifications of sub-disciplines in management sciences in Polish and worldwide research practice. The aim is realized on the basis of the study of 13 selected classifications and opinions of 31 experts representing the scientific community from Poland and China.

The first section of the paper presents a literature review and 13 analyzed classifications. Then the research methodology and the respondents' characteristics are discussed. The next part presents the results of the research aimed at achieving the goal of the paper. In the final section of the paper, attention is drawn to the limitations and directions of further research and the most important conclusions of the empirical work are presented.

\footnotetext{
" In the paper, the term "sub-discipline" and "specialization" will be used interchangeably. However, the literature also presents approaches distinguishing these concepts, e.g.: M. Soliwoda (2012, p. 337), who states that "a scientific sub-discipline is part of a scientific discipline, part of science in the institutional sense, distinguished on the basis of the subject and goal of research, while a research specialization is a set of developed and distinguished parts of knowledge about reality systematized on the basis of the object and goals of the cognitive process and social importance of its results."
} 


\section{LITERATURE REVIEW AND CHARACTERISTICS OF ANALYZED CLASSIFICATIONS}

An important feature of management sciences is their sub-disciplinary nature which results in distinguishing specific research specializations. From the general perspective, it results from the hierarchical division of sciences into specific (Michałek, 2008, p. 156): (1) Domains $\rightarrow$ (2) Disciplines $\rightarrow$ (3) Sub-disciplines/Specializations $\rightarrow$ (4) Research areas $\rightarrow$ (5) Problems $\rightarrow$ (6) Issues $\rightarrow$ (7) Tasks. From the specific perspective, it is a result of (Nogalski \& Cyfert, 2016):

- the eclectic nature of management sciences that combine achievements and traditions of many areas of science by absorbing research elements useful from the perspective of management,

- the complexity and heterogeneity of practical and theoretical issues that management sciences deal with,

- the use of a wide variety of criteria to define and distinguish objects, conceptual constructs and events forming the basis of scientific considerations,

- the utilitarian nature of the sciences that develop and evolve in response to practical needs, which translates into their increased dynamics compared to other, more traditional areas of science,

- the need to institutionalize this discipline and the possibility of determining the areas of interest of researchers involved in management sciences.

O. Flak (2012) indicates the historical context for the emergence of sub-disciplines in management sciences stimulated by two overlapping yet contradictory trends of differentiation and integration of research areas. E. Masłyk-Musiał (2010, p. 15) emphasizes that this sub-disciplinary and inter-disciplinary diversity of management sciences is their strength, as a complex organizational reality requires a comprehensive diagnosis of organizational issues and the merging of different areas of knowledge in the field of management. S. Sudoł (2014, pp. 29-31) confirms that distinguishing sub-disciplines in management sciences is associated with a number of benefits, including, among others, rising the rank and recognizing the autonomy of particular specializations, enhancing research methods and integrating the scientific community.

Discussions about the importance and scope of sub-disciplines actually integrate academia, as illustrated by the example of the 
gathering at the National Scientific Conference "Summer School of Management" entitled "Challenges and Prospects for the Development of Management Sciences" organized in 2010 by the Committee of Organization and Management Sciences of the Polish Academy of Science and the Department of Management at the Faculty of Organization and Management of Lodz University of Technology. Deliberations focused around such sub-disciplines as (Lachiewicz \& Nogalski, 2010): (1) strategic management, (2) human resources management, (3) change management, (4) knowledge management, (5) innovation management, (6) study of the organization, (7) corporate governance, (8) public management, (9) resource management, (10) small and medium-sized enterprises management, (11) methods of organization and management, (12) quality management, (13) logistics and (14) international management.

There is no unequivocal and generally accepted classification of sub-disciplines in the national and international community of management sciences. This results, among others, from the existence of various objectives of creating such classifications and application of different classification criteria, including: types of organizations, processes, resources, functions, areas, levels as well as concepts and methods of management (Sudoł, 2012, p. 37). The challenge lies also in their strong inter-sub-disciplinary nature manifested in the substantive overlap and complementarity between different disciplines of management sciences.

This sub-disciplinary nature also has a very dynamic character. It manifests in attempts to raise the rank of particular sub-disciplines (e.g.: Staniec, 2012) as well as to distinguish new specializations, e.g.: arts management (Evrard \& Colbert, 2000) or sport management (van der Roest et al., 2015). This sub-disciplinary nature of management sciences is also subject to the trend of transformation of individual specializations into independent scientific disciplines. For instance, in the current classification of sciences in Poland, finance is a separate scientific discipline (Regulation of the Minister of Science and Higher Education of 8 August 2011), and similar proposals are also formulated for logistics (Brzeziński, 2008) or marketing (Kamiński, 2016).

As a result, many different approaches to objectives, rules, logic and criteria of classification and division of research specializations are used in the Polish and international research practice. On the basis of a review of the literature and electronic resources, the following 
classifications which include certain sub-disciplines of management sciences are analyzed:

1. The proposal of S. Sudoł developed in the framework of work undertaken by the Team of the Committee of Organization and Management Sciences of the Polish Academy of Science. In 2007, S. Sudoł (p. 43) proposed a division of management sciences into 4 general sub-disciplines encompassing: (1) general theories of management, administration and command, (2) management of economic organizations, (3) engineering management (technology and production processes) and (4) public management. His proposals were subsequently modified in 2014, when S. Sudol (p. 31) proposed 3 general specializations divided on the basis of the subject terms: (1) theoretical foundations of management, (2) management of commercial organizations and (3) management in public organizations. He also pointed out that in the development of management sciences a wider division of 10 sub-disciplines may be useful, including. among others: strategic management, human resources management, marketing and quality management.

2. The proposal of the Committee of Organization and Management Sciences of the Polish Academy of Science* (OM PAS) which encompassed 21 sub-disciplines of management sciences based on a hierarchical set of 3 criteria: empirical criterion, subject criterion and management-level criterion (including strategic, operational and functional levels) (Cyfert et al., 2014).

3. The proposal of the Committee of Economic Sciences of the Polish Academy of Science (Cyfert et al., 2014, p. 40). It includes 6 sub-disciplines of management sciences distinguished in order to determine the nature and scope of this discipline within the field of economics.

4. The classification of sciences developed in the framework of panels of the National Science Centre (Panele NCN). It encompasses 3 general panels relating to the areas of science, and then specific panels expressing particular scientific disciplines and sub-disciplines.

\footnotetext{
The proposal was developed on the basis of the work conducted by the Team for the Determination of Sub-disciplines in Management Sciences established on the initiative of Bogdan Nogalski, PhD Habilitated, the Chairman of the Committee of Organization and Management Sciences of the Polish Academy of Science. The Team included the following participants: Szymon Cyfert, PhD Habilitated (UE) - the Chairman, Wojciech Dyduch, PhD Habilitated (UE), Dominika Latusek-Jurczak, PhD Habilitated (ALK), Jerzy Niemczyk, PhD Habilitated (UE) and Agnieszka Sopińska, PhD Habilitated (SGH).
} 
Sub-disciplines characteristic of management sciences are located in HS4 panel: entity, institutions, markets. They include: econometrics and statistical methods, resources and sustainable development, banking, corporate finance, accounting, consumption and consumer behavior, marketing, organizational management, strategic management, concepts and methods of management, logistics, human resources management, employment and wages as well as public administration. The classification is open as one can add related issues in HS4_16 panel.

5. The 6-digit UNESCO nomenclature for fields of science and technology (1988) which distinguishes 24 various fields of science, including economic sciences (code 53), divided into 13 disciplines. Sub-disciplines of management sciences are located in the discipline of organization and management of enterprises (code 5311). It includes 10 sub-disciplines along with the possibility of taking into account other proposals.

6. The classification of the Academic Degrees Committee of the State Council (ADCSC Classification, 2011) used in China, in which management sciences encompass 5 sub-disciplines: (1) management science and engineering, (2) business management, (3) agriculture and forestry economics, (4) public management, as well as (5) library and information management. Its main objective is to identify the specializations in the framework of which academic degrees and professional titles are granted at universities.

7. The Australian and New Zealand Standard Research Classification ANZSRC (Pink \& Bascand, 2008), which encompasses a total of 22 science divisions, including division no. 15: commerce, management, tourism and services. This division encompasses 7 groups of scientific issues. Sub-disciplines of management sciences can be found in all 7 of them with the exception of group no. 1506: tourism. A total of 40 sub-disciplines, along with the possibility of including other proposals, are distinguished.

8. The classification of the EURAM Strategic Interest Groups adopted in 2009 in the framework of the European Academy of Management. It includes an internal division of management sciences into 13 sub-disciplines such as: business for society, corporate governance, entrepreneurship, gender, race and diversity in organizations, managing sport, project organizing, public and non-profit management, as well as strategic management. 
9. The Italian ANVUR classification (2015) used by the National Agency for Evaluation of the University System and Research (Agenzia Nazionale di Valutazione del Sistema Universitario e della Ricerca). Its internationalized version prepared by Consiglio Universitario Nazionale identifies 4 sub-disciplines of management sciences in the framework of macro-sector no. 13/B: business administration and management.

10. The classification of domains of interest in the framework of the European Institute for Advanced Studies in Management (EIASM). This is an internal division of management science into 112 sub-disciplines determined at two levels, including 19 sub-disciplines on level 1 and 93 on level 2. The classification is open, with the possibility of adding other proposals.

11. The classification of the European Group for Organizational Studies (EGOS classification). The organization operates in the framework of dynamically functioning working teams, the socalled Standing Working Groups (SWGs), conducting research in a specific area. Currently 13 SWGs have been designated, including: the changing role of business in global society, creative industries, organizational ethnography, organizational paradox: engaging plurality, tensions and contradictions, doing process research, institutions, innovation, impact: how institutional theory matters as well as emotions in social contexts: relational, organizational, and institutional implications.

12. The classification of Divisions \& Interest Groups of the Academy of Management (DIG AoM) encompassing 25 specializations integrating AoM members within specific teams. These areas are described in detail within the so-called domain statements expressing the specificities of each research domain. This classification is rather closed, however, changes occur within in, especially in the names of DIGs, associated with the development of management sciences.

13. The classification of Web of Science Subject Areas (WoS SA), used to classify scientific journals to each thematic category. These categories are grouped under the following three indices: (1) Science Citation Index Expanded Journals, (2) Social Sciences Citation Index Journals and (3) Arts \& Humanities Citation Index Journals. The list of the specializations characteristic of management sciences is included in Index 2: Social Sciences 
Citation Index Journals, encompassing a total of 57 categories.

12 areas, which include the management context, belong to sub-disciplines of management sciences.

A detailed analysis of the scope, characteristics and possibilities of using these classifications in research practice was carried out as part of empirical research. The report on the analysis is presented further on in the paper.

\section{RESEARCH METHODOLOGY}

The aim of the paper is realized on the basis of empirical research carried out with the use of triangulation (Stańczyk, 2015) encompassing: (1) the document research method (Chybalski \& Matejun, 2013, pp. 134-136) and (2) the research method for expert opinions survey (Mahmoud, 2015).

In the framework of the document research method, the technique of content analysis was used. Sources of information included 4 national and 9 international classifications of sub-disciplines presented in the theoretical part.

20 scientists representing management sciences from Poland and 11 from China participated in the study of experts' opinions. Intentional selection of opinions of experts from Poland and China was made due to significant substantive differences in Polish (European) and Chinese classifications of sub-disciplines in management sciences. This approach made it possible to assess whether the formal differences affect the diversity of experts' opinions with regard to scope, characteristics and prospects for the development of classifications of sub-disciplines in management sciences in research practice.

The study was carried out within the framework of scientific cooperation among Lodz University of Technology (Poland), the University of Lodz (Poland) and Chongqing Jiaotong University (China). The survey technique was used as the research technique and an original expert questionnaire containing 12 questions and the respondents' particulars was the research tool. The study was conducted in the period September-December 2017.

The group of experts was dominated by independent researchers: full professors (7 persons) and associate professors (14 persons). Assistant professors (7 persons), 2 lecturers and 1 assistant also 
participated in the research. The selection of experts for the research sample was purposeful. Invitations were sent to the faculty of the Economics and Management School at Chongqing Jiaotong University, representatives of the Committee of Organization and Management Sciences of the Polish Academy of Science and scientists who have expressed interest in the survey. The respondents represented a variety of research interests, including: various concepts and methods of management, marketing, logistics, and finance management, human resources management, entrepreneurship, innovativeness and public management. The period of their scientific activity was usually more than 20 years (10 experts) or from 6 to 10 and 11-15 years (7 experts respectively). For their involvement, the experts received a certificate confirming their participation in the study.

\section{RESULTS AND DISCUSSION}

4 national and 9 foreign classifications of sub-disciplines in management sciences, presented in the theoretical part of the paper, were selected. They have been formulated by scientific communities, organizations of scientists, as well as public institutions (regulatory bodies). Their objectives differ. From the general perspective, they relate to the search for identity, internal structure and directions of evolution and development of management sciences. At the specific level, individual classifications were formulated in order to:

- integrate the scientific community (e.g.: S. Sudoł, OM PAS),

- fulfill statistical obligations (e.g.: UNESCO, ANZSRC),

- evaluate scientific and teaching activity carried out by universities (e.g.: ANVUR),

- determine the profile of activity and research interests of scientists (e.g.: EURAM, EIASM, DIG AoM),

- distribute funds for scientific research (e.g.: NCN),

- grant academic degrees and professional titles within specializations (e.g.: ADCSC),

- build and develop research teams (e.g.: EGOS),

- classify scientific journals (e.g.: WoS SA).

Detailed characteristics of the analyzed classifications of sub-disciplines in management sciences are presented in Table 1. 
Table 1. Characteristics of the analyzed classifications of sub-disciplines in management sciences

\begin{tabular}{|l|l|l|c|c|c|}
\hline Classification & Country/Area & Scope & $\begin{array}{c}\text { Levels of } \\
\text { classification }\end{array}$ & $\begin{array}{c}\text { Number of } \\
\text { sub-disciplines }\end{array}$ & Boundaries \\
\hline S. Sudoł 2014 & Poland & specific & 1 & 10 & closed \\
\hline OM PAS & Poland & specific & 4 & 21 & closed \\
\hline Econ PAS & Poland & specific & 1 & 6 & closed \\
\hline NCN & Poland & general & 2 & 14 & open \\
\hline UNESCO & International & general & 1 & 10 & open \\
\hline ADCSC & China & general & 1 & 5 & closed \\
\hline ANZSRC & Australia and & general & 2 & 40 & open \\
\hline EURAM & Europe & specific & 1 & 13 & closed \\
\hline ANVUR & Italy & general & 1 & 4 & closed \\
\hline EIASM & Europe & specific & 2 & 112 & open \\
\hline EGOS & Europe & specific & 1 & 13 & open \\
\hline DIG AoM & USA & specific & 1 & 25 & closed \\
\hline WoS SA & International & general & 1 & 12 & closed \\
\hline
\end{tabular}

Source: own study based on research results.

The analyzed classifications are diverse in their nature and scope. Half of these classifications are general, which means that they are part of larger classifications encompassing different scientific areas and research disciplines. The other half are specific classifications, which means that they are dedicated only to the classification of sub-disciplines that are part of management sciences. Most of the analyzed classifications (9 out of 13) identify sub-disciplines only on one equal level. In the case of three classifications, two levels are used, introducing a certain hierarchy to the division of specializations. The OM PAS classification is an interesting case, as it consists of 4 levels of division but they refer mostly to the criteria on the basis of which the sub-disciplines belonging to the lowest level are distinguished. However, since those criteria help distinguish substantive subsets in management sciences, one can treat them also as levels for distinguishing sub-disciplines. In the analyzed subset, more than half of classifications are closed classifications (8 out of 13), which do not assume the possibility of adding extra sub-disciplines by the user.

In the analyzed classifications, the number of sub-disciplines differs quite clearly and ranges from $\mathrm{Min}=4$ to $\mathrm{Max}=112$. The average number 
of sub-disciplines within the classifications calculated as median was $\mathrm{Mdn}=13$, at relatively high standard deviation $\mathrm{SD}=28.75$, this is, however, mainly due to the presence of an outlier in the form of the EIASM classification. There are no significant differences between the average number of general $(\mathrm{Mdn}=11)$ and specific $(\mathrm{Mdn}=11)$ classifications as well as between closed $(\mathrm{Mdn}=11)$ and open $(\mathrm{Mdn}$ =14) classifications.

A lack of consideration of the rules of logical division is an important limitation of the analyzed classifications (Ziembiński, 2004, pp. 56-62). Due to a lack of designation of clear substantive boundaries of management sciences, there are problems with fulfilling the rule of exhaustivity, as illustrated by the example of the inclusion of the following specializations in sub-disciplines of management sciences: "library and information management" in the ADCSC classification or "health policy \& services" in the DIG AoM classification. The challenge lies also in the determination of the specific nature of each sub-discipline, which often results in their significant substantive similarity leading to the violation of the rule of exclusivity. For instance, the similarity of the "strategic management" sub-discipline to such specializations as "strategic human resource management" and "strategic issues in international business" in the EIASM classification. In the analyzed classifications, different criteria at the same level of division are often used to distinguish sub-disciplines, which violates the rule of essentialism. For example, the following sub-disciplines: "organizational behavior" (levels of management criterion) and "public and non-profit management" (subject criterion) in the EURAM classification.

In order to verify the possibility of using the analyzed classifications in research practice, a study of opinions provided by experts - representatives of management sciences from Poland and China - was conducted. In the first part of the study, the respondents were asked what best/the optimal number of sub-disciplines in management sciences should be. They were able to choose from closed numeric intervals increasing every 10 sub-disciplines and one half-open division of above 100 sub-disciplines. The experts favored a relatively small number of sub-disciplines. Most of the respondents (84\%) said that the number of sub-disciplines should not exceed 20 , while $58 \%$ stated that the optimal level of division was from 11 to 20 specializations. The average number of preferred sub-disciplines was $M d n=15,50$, at relatively high standard deviation $\mathrm{SD}=26$. There was no differences in 
the responses of the respondents from Poland and China. The results indicate that the preferred by the experts number of sub-disciplines is coincident with the average number of specializations found in the analyzed classifications. High values of standard deviation in both studies indicate, however, significant discrepancies in this respect.

In the next question, the experts were asked to indicate the 2-3 currently most important sub-disciplines in management sciences. The question was open-ended, and the respondents had complete freedom of expression. All the respondents submitted their proposals, ranking human resources management ( 8 responses) and marketing (7 responses) as the most important sub-disciplines. The following sub-disciplines were also mentioned as important:

- project management (6 responses),

- logistics (4 responses, with supply chain management added to the sub-discipline, the number of responses increased to 6),

- strategic management, finance management, knowledge management and business process management (4 responses),

- production management, system management, as well as management science and engineering (3 responses).

To a lesser extent, the following sub-disciplines were also proposed: innovation management, research methodology in management sciences, psychology and business administration (2 responses respectively). The experts also formulated the following single proposals: risk management, change management, public management, value management, small business management, operation research and information management.

The analysis also indicates that more than half of the experts (58\%) pointed to specializations that were within the scope of their own research interests as the most important sub-disciplines in management sciences. This may indicate high subjectivity of sub-discipline identification by researchers. This indicator was notably two times greater in the case of Polish experts (70\%) than the researchers from China (36\%). Then an analysis of the range of occurrence of proposed sub-disciplines (3 or more responses) in the analyzed classifications was conducted. The results are presented in Table 2 .

The results indicate that there is quite a strong relationship, $r_{x y}(N=11)=0.67$, between the number of the experts' responses pointing to particular sub-disciplines and the range of their occurrence in the analyzed classifications. The OM Committee PAS classification, 
encompassing 9 out of 11 most often indicated sub-disciplines, is characterized by the best fit. This is confirmed by a statement made by one of the experts: "In general, I believe the division of sub-disciplines made by the team of the OM Committee PAS to be successful, apart from a lack of risk management." Interestingly, the EIASM classification identifying more than 100 specializations is characterized by the lowest level of fit. The results obtained were definitely influenced by the cultural diversity of the respondents. For example, the "management science and engineering" sub-discipline was indicated only by the representatives from China, as it occurs only in the Chinese ADCSC classification.

Table 2. The range of occurrence of sub-disciplines proposed by the experts in the analyzed classifications

\begin{tabular}{|c|c|c|c|c|c|c|c|c|c|c|c|c|c|c|}
\hline $\begin{array}{l}\text { Sub-disciplines of } \\
\text { management sciences: }\end{array}$ & 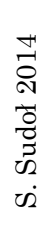 & $\frac{\sum_{1}^{2}}{\sum_{0}^{2}}$ & 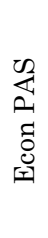 & $\begin{array}{l}Z \\
\text { Z } \\
Z\end{array}$ & 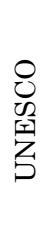 & $\begin{array}{l}0 \\
\text { Un } \\
\text { 岁 }\end{array}$ & 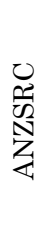 & 空 & 号 & 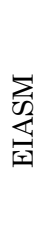 & $\begin{array}{l}0 \Omega \\
0 \\
0 \\
\text { I }\end{array}$ & 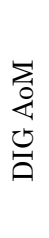 & 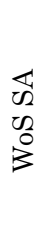 & 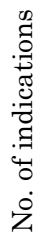 \\
\hline $\begin{array}{l}\text { Human resources } \\
\text { management }\end{array}$ & $\mathrm{X}$ & $\mathrm{X}$ & & $\mathrm{X}$ & $\mathrm{X}$ & & $\mathrm{X}$ & & $\mathrm{X}$ & $\mathrm{X}$ & $\mathrm{X}$ & $\mathrm{X}$ & $\mathrm{X}$ & 10 \\
\hline Marketing & $\mathrm{X}$ & $\mathrm{X}$ & & $\mathrm{X}$ & $\mathrm{X}$ & & $\mathrm{X}$ & & & $\mathrm{X}$ & & & & 6 \\
\hline Project management & $\mathrm{X}$ & $\mathrm{X}$ & & & & & & $\mathrm{X}$ & & & & & & 3 \\
\hline Logistics & $\mathrm{X}$ & $\mathrm{X}$ & & $\mathrm{X}$ & & & $\mathrm{X}$ & & & $\mathrm{X}$ & & $\mathrm{X}$ & $\mathrm{X}$ & 7 \\
\hline Strategic management & $\mathrm{X}$ & $\mathrm{X}$ & $\mathrm{X}$ & $\mathrm{X}$ & & & & $\mathrm{X}$ & & $\mathrm{X}$ & & $\mathrm{X}$ & & 7 \\
\hline Finance management & & $\mathrm{X}$ & & $\mathrm{X}$ & $\mathrm{X}$ & & $\mathrm{X}$ & & $\mathrm{X}$ & $\mathrm{X}$ & & & $\mathrm{X}$ & 7 \\
\hline Knowledge management & & $\mathrm{X}$ & & & & & $\mathrm{X}$ & & & $\mathrm{X}$ & & & $\mathrm{X}$ & 4 \\
\hline $\begin{array}{l}\text { Business process } \\
\text { management }\end{array}$ & & $\mathrm{X}$ & & & & & & & & & & & & 1 \\
\hline Production management & $\mathrm{X}$ & $\mathrm{X}$ & & & $\mathrm{X}$ & & & & & $\mathrm{X}$ & & & & 4 \\
\hline System management & & & & & & & & & & & & & & 0 \\
\hline $\begin{array}{l}\text { Management science and } \\
\text { engineering }\end{array}$ & & & & & & $\mathrm{X}$ & & & & & & & & 1 \\
\hline No. of indications: & 6 & 9 & 1 & 5 & 4 & 1 & 5 & 2 & 2 & 7 & 1 & 3 & 4 & \\
\hline
\end{tabular}

Source: own study based on research results.

In the study, the experts were also asked about the characteristics and development prospects of classifications of sub-disciplines in management sciences. Each assessed item was expressed using two 
opposing variants, and the respondents had to indicate the preferred option. The results obtained on the basis of the dominant responses indicate that the surveyed experts prefer rather multiple-level divisions of management sciences where there is a hierarchical arrangement of sub-disciplines. The overall results indicate that a better solution is to distinguish a relatively small number of sub-disciplines which will be characterized by a greater substantive scope. The analysis of the diversity of results broken down by individual countries shows, however, differences in these opinions. In the case of the respondents from China, the dominant opinion is that the number of sub-disciplines should be relatively greater while their substantive scope should be reduced.

According to the experts, such classifications should also ensure substantive flexibility and take into account the possibility of adding or removing sub-disciplines depending on needs and directions of the development of management sciences. The challenge lies, however, in such a selection of sub-disciplines that they cover the appropriate scope of knowledge concerning management sciences. The opinions of the respondents on this issue are deeply divided. $42 \%$ of the respondents indicates that classifications of sub-disciplines should be chosen so that their scope covers the entire (as much as possible) substantive scope of management sciences. The same number of responses suggest that this is not necessary, and $16 \%$ of the respondents has no opinion on the subject. The problem with this answer is probably associated with a lack of unambiguous (generally acceptable) designation of the substantive scope of management sciences and many direct links with other scientific disciplines. National diversity of opinion can be also observed. The majority of the respondents from China (64\%) think that there is no possibility of such a selection of sub-disciplines that covers the entire scope of knowledge related to management sciences. Half of the Polish experts surveyed say, however, that it is possible and beneficial, but at the same time $20 \%$ of them does not have a definite opinion on the subject.

The respondents' opinions suggest that in the future one should expect an increase in the number of sub-disciplines in management sciences accompanied by a trend to limit their substantive scope. The experts also predict that the sub-disciplinary nature of management sciences will evolve in the direction of merging and absorbing substantive areas from different related disciplines, such as, for example, economics or engineering sciences. 


\section{LIMITATIONS AND FUTURE DIRECTIONS OF RESEARCH}

The main limitation of the conducted research was a small research sample, both in terms of the analyzed classifications and the experts providing responses. Therefore, the results obtained cannot be regarded as representative. One can only hope that the international nature of the research allows to capture a wider context of challenges associated with the development of classifications of sub-disciplines in management sciences. The experts' statements and opinions can be thought of as the voice of just some part of the scientific community, which allows (limited) verification of the application of the analyzed classifications in research practice. The research will certainly be continued on larger samples. It is also planned to increase the geographic and cultural scope of analyses, which will allow to capture the diversity of approaches, expectations and perceptions of classifications of sub-disciplines in management sciences in different parts of the world.

\section{CONCLUSIONS}

The conducted research indicates significant diversity of approaches to constructing classifications of sub-disciplines in management sciences in Polish and worldwide research practice. The study also points to certain methodological, logical and substantive challenges in this respect, including:

- the problem of determination of objectives and criteria for making divisions and taking into account their specific or general nature,

- the problem of determination of names, the substantive scope and boundaries of particular sub-disciplines,

- the problem of interaction of sub-disciplines in management sciences with substantive areas of other fields or scientific disciplines,

- the problem of distinguishing a certain number of sub-disciplines and their hierarchy at specific levels of classification,

- the problem of defining boundaries, conditions and rules for expanding or reducing the scope of classifications, 
- the problem of ensuring rules of logical distribution in the framework of divisions made,

- the problem of potential subjectivity on the part of people preparing classifications associated with favoring research specializations represented by them,

- the problem of geographical and cultural differences related to history, traditions and scientific achievements in the area of management sciences,

- the problem of taking into account the expectations and voice of the scientific community when constructing divisions,

- the problem of measuring the impact of classifications on achievements, integration and development prospects of management sciences.

Undoubtedly it is not possible or necessary to create a universal classification acceptable throughout the entire scientific community. The results obtained indicate, however, that the analyzed classifications in many cases correspond in terms of their size and practical usefulness to the expectations of the surveyed experts. Perhaps their improvements should focus on the discussion on the number of levels of classification, hierarchy of sub-disciplines as well as rules and conditions for adding and removing specializations depending on needs or directions of the development of management sciences. However, a more extensive voice of the scientific community is necessary in this matter. Therefore, it is planned to continue the research with the hope that its results will provide in-depth guidelines and conclusions regarding the scope, directions and logic of constructing classifications of sub-disciplines in management sciences.

\section{REFERENCES}

ADCSC classification (2011). Ministry of Education of the People's Republic of China.

Retrieved from: http://old.moe.gov.cn//publicfiles/business/ htmlfiles/moe/ moe_834/201104/116439.html (access: 10.01.2018).

ANVUR classification (2015). Consiglio Universitario Nazionale. Retrieved from: https://www.cun.it/uploads/4079/Allegato_CAcademicFieldsand Disciplines. pdf? $\mathrm{v}=$ (access: 10.01.2018).

Brzeziński, M. (2008). Podstawy logistyki jako dyscypliny naukowej. Logistyka, $5,76-77$. 
Chybalski, F. \& Matejun, M. (2013). Organizacja jako obiekt badań - od zbierania danych do analizy wyników. In: A. Adamik (ed.), Nauka o organizacji. Podejście dynamiczne (pp. 93-151). Warszawa: Oficyna a Wolters Kluwer business.

Cyfert, S., Dyduch, W., Latusek-Jurczak, D., Niemczyk, J. \& Sopińska, A. (2014). Subdyscypliny w naukach o zarządzaniu - logika wyodrębnienia, identyfikacja modelu koncepcyjnego oraz zawartość tematyczna. Organizacja i Kierowanie, 1(161), 37-49.

DIG AoM: Divisions \& interest groups of the Academy of Management (n.d.). Academy of Management. Retrieved from: http://aom.org/DIG/ (access: 25.01.2018).

EGOS classification (n.d.). European Group for Organizational Studies. Retrieved from: https://www.egosnet.org/swgs/current_swgs (access: 27.01.2018).

EIASM domains of interest (n.d.). European Institute for Advanced Studies in Management. Retrieved from: http://www.eiasm.net/ (access: 27.01.2018).

EURAM strategic interest groups (2009). European Academy of Management. Retrieved from: http://www.euram-online.org/2016-04-18-09-30-12.html (access: 10.01.2018).

Evrard, Y. \& Colbert, F. (2000). Arts management: A new discipline entering the millennium? International Journal of Arts Management, 2(2), 4-13.

Flak, O. (2012). Istota nauk o zarządzaniu na początku wieków XX i XXI. In: A. Czech (ed.), Nauki o zarzqdzaniu - u poczqtków i współcześnie (pp. 199-212). Zeszyty Naukowe Wydziałowe UE W Katowicach, Katowice: Wydawnictwo UE w Katowicach.

Gorynia, M. (2013). Klasyfikacja nauk ekonomicznych-dywergencja czy konwergencja? Committee of Economic Sciences of the Polish Academy of Sciences. Retrieved from: http://www.kne.pan.pl/images/stories/pliki/Gorynia\%20 Klasyfikacja\%20nauk\%20ekonomicznych.pdf (access: 25.01.2018).

Kamiński, J. (2016). Refleksje nad zakresem nauki o marketingu jako dyscypliny naukowej, cz. 1. Marketing i Rynek, 6, 2-12.

Lachiewicz, S. \& Nogalski, B. (eds.) (2010). Osiagnięcia i perspektywy nauk o zarzqdzaniu. Warszawa: Oficyna a Wolters Kluwer business.

Łupicka, A. (2014). New paradigms in management sciences: The conceptual analysis. Research in Logistics \& Production, 4(1), 67-79.

Mahmoud, R. (2015). A review of the expert opinion technique and recommendations to reduce its bias. Format: Forecast and Road Mapping for Manufacturing Technologies. Retrieved from: http://www.format-project.eu/deliverables/ white-papers/january-2015-a-review-of-the-expert-opinion-technique-and-recommendations -to-reduce-its-bias/at_download/file (access: 20.12.2017).

Masłyk-Musiał, E. (2010). Badawcze wyzwania w naukach o zarządzaniu. In: S. Lachiewicz \& B. Nogalski (eds.), Osiagnięcia i perspektywy nauk o zarzqdzaniu (pp. 15-29). Warszawa: Oficyna a Wolters Kluwer business. 
Mendes, A.M.O.C. (2016). Science classification, visibility of the different scientific domains and impact on scientific development. Journal of Nursing Referência, 4(8), 143-149.

Michałek, R. (2008). Głos w sprawie klasyfikacji nauk. Nauka, 3, 155-159.

Mingers, J. \& Leydesdorff, L. (2015). Identifying research fields within business and management: A journal cross-citation analysis. Journal of the Operational Research Society, 66(8), 1370-1384.

Nogalski, B. \& Cyfert, S. (2016). Zakres problemowy prac habilitacyjnych w naukach o zarzadzaniu w latach 2007-2015. "II Spotkanie z zarządzaniem" conference website. Retrieved from: https://zie.pg.edu.pl/kz/relacje-ze-spotkan/-/ asset_publisher/eL7ul6TGmRrJ/content/ii-spotkanie-z-zarzadzaniem-28-kwietnia-2016 (access: 10.01.2018).

Panele NCN (n.d.). National Science Center. Retrieved from: http://ncn.gov.pl/ finansowanie-nauki/panele-ncn (access: 10.01.2018).

Pink, B. \& Bascand, G. (2008). Australian and New Zealand standard research classification ANZSRC. Australian Bureau of Statistics. Australian Research Council. Retrieved from: http://www.ausstats.abs.gov.au/Ausstats/ subscriber. nsf/0/2A3A6DB3F4180D03CA25741A000E25F3/\$File/12970_2008.pdf (access: 10.01.2018).

Rozporządzenie MNiSW z dnia 8 sierpnia 2011 w sprawie obszarów wiedzy, dziedzin nauki i sztuki oraz dyscyplin naukowych i artystycznych, Dz.U. 2011, Nr 179, poz. 1065.

Soliwoda, M. (2012). System i zakres informacyjny rachunkowości zarządczejewolucja zmian. In: A. Czech (ed.), Nauki o zarzqdzaniu - u poczqtków i wspótcześnie (pp. 333-346). Zeszyty Naukowe Wydziałowe UE W Katowicach, Katowice: Wydawnictwo UE w Katowicach.

Staniec, I. (2012). Zarządzanie ryzykiem w naukach o zarządzaniu. In: A. Czech (ed.), Nauki o zarzqdzaniu - u poczatków i współcześnie (pp. 259-272). Zeszyty Naukowe Wydziałowe UE W Katowicach, Katowice: Wydawnictwo UE w Katowicach.

Stańczyk, S. (2015). Triangulacja - łączenie metod badawczych i urzetelnianie badań. In: W. Czakon (ed.), Podstawy metodologii badań w naukach o zarzadzaniu (pp. 243-265). Warszawa: Oficyna a Wolters Kluwer business.

Sudoł, S. (2007). Nauki o zarzadzaniu. Węłowe problemy i kontrowersje. Torun: Dom Organizatora.

Sudoł, S. (2012). Nauki o zarzadzaniu. Warszawa: PWE.

Sudoł, S. (2014). Podstawowe problemy metodologiczne nauk o zarządzaniu. Organizacja i Kierowanie, 1(161), 11-35. 
UNESCO nomenclature for fields of science and technology (1988). Unesco. Retrieved from: http://unesdoc.unesco.org/images/0008/000829/ 082946eb.pdf (access: 10.01.2018).

van der Roest, J.W., Spaaij, R. \& van Bottenburg, M. (2015). Mixed methods in emerging academic sub-disciplines: The case of sport management. Journal of Mixed Methods Research, 9(1), 70-90.

WoS SA: Web of Science subject areas (n.d.). Clarivate Analytics. Retrieved from: http://mjl.clarivate.com/scope/scope_ssci/ (access: 10.01.2018).

Zakrzewska-Bielawska, A. (2012). Istota procesu zarządzania. In: A. Zakrzewska-Bielawska (ed.), Podstawy zarzadzania. Teoria i ćwiczenia (pp. 15-40). Warszawa: Oficyna a Wolters Kluwer business.

Ziembiński, Z. (2004). Logika praktyczna. Warszawa: Wydawnictwo Naukowe PWN. 


\section{SUBDYSCYPLINY W NAUKACH O ZARZAQDZANIU: KLASYFIKACJA W POLSKIEJ I ŚWIATOWEJ PRAKTYCE BADAWCZEJ}

Jedną z cech nauk o zarządzaniu jest silna subdyscyplinarność wyrażająca tendencje do wyodrębniania określonych specjalności badawczych. Proces ten wynika z eklektycznego charakteru zarządzania i wiąże się z dynamicznym wyłanianiem się nowych obszarów badawczych i zastosowań praktycznych. Biorac to pod uwagę, jako cel artykułu wyznaczono identyfikację i ocenę zakresu, cech charakterystycznych oraz perspektyw rozwoju wybranych klasyfikacji subdyscyplin nauk o zarządzaniu w polskiej i światowej praktyce badawczej. Realizacji celu poświęcono badania 13 wybranych klasyfikacji oraz opinii 31 ekspertów reprezentujących środowisko naukowe z Polski i z Chin. Wyniki wskazują na dużą różnorodność analizowanych klasyfikacji, które charakteryzują się różnymi celami stosowania, zakresem, cechami charakterystycznymi oraz logiką wyodrębnienia.

Słowa kluczowe: nauki o zarządzaniu, subdyscypliny w naukach o zarządzaniu, klasyfikacja nauk, tożsamość nauk o zarządzaniu. 